\title{
Çocukluktaki Aile İçi Şiddet Öyküsü ile Flört Şiddeti Arasındaki İlişkinin İncelenmesi
}

\author{
Veda Bilican Gökkayaa , Meral Öztürkb,c
}

\section{Özet}

Anahtar Kelimeler

Araştırma, flört şiddeti uygulama/flört şiddetine maruz kalma ile çocukluktaki aile içi şiddet öyküsü (ebeveynler arasındaki şiddete tanıklık etmek, şiddete maruz kalmak, maruz kalınan şiddetin türü) arasındaki ilişkiyi ortaya koymaktadır. Araştırma, ilişkisel tarama modeline dayanmaktadır. Çalışmada kişisel bilgi formu ile araştırmacılar tarafından hazırlanan anket formu kullanılmıştır. Çalışmaya 792 üniversite öğrencisi katılmıştır. Verilerin analizinde Ki-Kare Bağımsızlık Testi kullanılmıştır. Bulgulara göre katılımcıların hem şiddet faili hem de mağduru olma düzeyleri yüksek olup, en sık uyguladıkları/maruz kaldıkları şiddet türü psikolojik şiddet eylemleridir. Çocukluğunda aile içi şiddete tanıklık edenler, ilişkilerinde hem daha çok flört şiddeti uygulamakta hem de flört şiddetine daha fazla maruz kalmaktadır. Çocukluğunda aile içi şiddete bizzat maruz kalma ile flört şiddeti uygulama arasında bir ilişki yoktur ancak çocukken şiddet mağduru olanlar, ilişkilerinde flört şiddetine daha sık maruz kalmaktadır. Son olarak, uğranılan şiddetin türü ile flört şiddeti uygulama/maruz kalma arasında bir ilişki yoktur. Bulgular, çocukluk çağı şiddet öyküsünün flört ilişkisindeki şiddet faili olma ve mağduriyetin önemli belirleyicisi olduğunu ortaya koymaktadır.

\section{An Investigation of the Relationship between History of Domestic Violence in Childhood and Dating Violence}

\section{Abstract}

This study analysed the relationship between using and receiving dating violence and the history of family violence in childhood (witnessing violence between parents, being subjected to violence and the type of violence experienced). The research was based on the correlational model. In the study, a personal information form and a questionnaire developed by the researchers were used. 792 students from various departments in different universities participated in the study. In the analysis of the data Chi-Square Test of Independence was performed to reveal the relationship between variables. According to the findings, the participants' level of being perpetrators and victims was quite high. Psychological violence was the most frequently used and received type of violence by participants. Witnessing family violence in childhood increased both using and receiving violence. There was no relationship between being exposed to family violence and being a perpetrator, but those who experienced violence in childhood were more likely to be victims of violence in dating relationships Finally, no relationship has been found between the type of domestic violence experienced in childhood and being a perpetrator/victim in a dating relationship. Findings reveal that childhood experiences of family violence are important determinants of violence in a dating relationship.
Keywords

Violence

Domestic violence

Dating

Dating violence

About Article

Received: 29.06.2021

Accepted: 15.12.2021

Doi: 10.18026/cbayarsos. 959425

aDoç. Dr., Sivas Cumhuriyet Üniversitesi/Merkez-Sivas / ORCID: 0000-0001-5083-6445

b İletişim Yazarı: mrozturk@cumhuriyet.edu.tr

cDoç. Dr., Sivas Cumhuriyet Üniversitesi/Merkez-Sivas / ORCID: 0000-0001-7570-5361 


\section{Giriş}

İnsan hakları çerçevesinde bir hak ihlali olarak karşımıza çıkan şiddet, bireylerin yaşam kalitesini düşüren, bedensel ve ruhsal sağlıklarını olumsuz yönde etkileyen ve bugün hemen hemen her toplumda mücadele edilen bir toplum sağlı̆̆1 sorunu olarak dikkat çekmektedir. “Birey ya da bireylerin yaşam, özgürlük, irade, istek, hak, sağllk ve iyi hallerini tehdit eden ya da gelişmesini engelleyen fiziksel, psikolojik, sosyal, cinsel, ekonomik, siber ya da işaretler yardımı ile uygulanan aşağılama, yaralama, zarar verme, mahrum bırakma, yalnızlaştırma gibi kötü niyetli ve kasıtlı davranışların tümü" (Offenhauer ve Buchalter, 2011; Özdere, 2019) olarak tanımlanan şiddet; yetişkinler arasında olduğu gibi flört ilişkisi içerisindeki ergen ve gençler arasında da yaygındır (Harned, 2002). Hatta flört şiddeti, evli çiftler arasındaki şiddete göre üç kat daha yaygındır (Straus, 2008).

Flört "sosyal etkileşim içeren ve ilişkiye devam ya da sonlandırma niyetiyle eylemlerde bulunulan, daha sonra bir tarafın ya da iki tarafın isteğiyle sonlandırılan ya da resmi bir ilişkiyle (evlilik, nişanlılık, birlikte yaşama) devam eden bir ilişki türüdür" (Avşar Baldan ve Akış, 2017: 41). Flört şiddeti ise "flört ilişkisinde partnere acı vermek ve yaralamak amacıyla gerçekleştirilen fiziksel veya psikolojik güç, tehdit ve kısıtlama içeren her türlü eylem"i (Sugarman ve Hotaling, 1998: 5) kapsamaktadır. Flört şiddetinde bilinenin aksine (şiddetin genelde erkekten kadına doğru olduğu düşünülse de) şiddet çift yönlü (birey hem fail/saldırgan hem de kurban) gerçekleşebilmektedir. Hem erkekler hem de kadınlar, flört şiddetini başlatabildikleri gibi şiddetin mağduru da olabilmektedirler. Elbette ki bu durum, her cinsiyetin eşit şekilde şiddet uyguladığı veya şiddete maruz kaldığı anlamına gelmemektedir (Maharaj, 2019).

Diğer şiddet türlerinde olduğu gibi flört şiddeti de bireylerde ciddi sağlık sorunlarına neden olmaktadır. Kısa dönemde yaralanma, hatta ölüm gibi etkiler söz konusu iken uzun dönemde travma sonrası stres bozukluğu, anksiyete, depresyon ve intihar düşüncesi ya da girişimi, alkol-sigara kullanımı, yeme bozuklukları, sağlıksız kilo alımı, anoreksiya, bulimiya, erken yaşta ilişkiye girme, çok sayıda partnerin olması, ilişki öncesi madde kullanımı, korumasız cinsel ilişkiye girme, cinsel yolla bulaşan hastalıklar, istenmeyen gebelikler, düşükler vb. görülebilmektedir (Avşar Baldan ve Akış, 2017: 42; Hatipoğlu, 2010: 21).

Flört şiddeti; fiziksel, psikolojik/duygusal, cinsel, ekonomik, sanal/dijital ve 1srarlı takip olarak karşımıza çıkabilmektedir. Fiziksel şiddet; çimdiklemek, tırmalamak, tokatlamak, yumruklamak, tekmelemek, sarsmak, bıçak, keski vb. aletlerle ateşli silahlarla yaralamak, öldürmek gibi davranışları kapsarken; psikolojik/duygusal şiddet; isim takmak, uygunsuz kelime kullanmak, eleştirmek, hakaret/küfür etmek, başkalarının yanında küçük düşürmek, utandırmak, değersiz, yetersiz ve suçlu hissettirmek, sevgi ve ilgi göstermemek, küsmek, aldatmak, kıskanmak, giyim ve davranışlarına müdahale etmek gibi davranışları kapsamaktadır. Cinsel şiddet; kişinin isteği dışında cinsel birliktelik için zorlamak, korunmadan cinsel ilişkiye zorlamak, doğum kontrol yöntemlerini kullanmamak ya da kullanılmasına izin vermemek, çocuk doğurmaya veya doğurmamaya zorlamak, cinsel içerikli mesajlar atmak, tecavüz, sözlü veya sözsüz cinsel taciz (Akcan, 2020; Aslan vd., 2020; Avşar Baldan ve Akış, 2017; Fidan ve Yeşil, 2018; Foshee vd., 2007; Kaplan, 2020; Özdere ve Kürtül, 2018; Sezer vd., 2020; Tuz vd., 2015; Yumuşak ve Şahin, 2014) şeklinde ortaya çıkarken ekonomik şiddet; partnerin çalışmasını engellemek ya da onu çalışmaya zorlamak, parasını kullanmak, parasına el koymak, para harcama özgürlüğünü elinden almak (Akış 
vd., 2019; Bilican-Gökkaya, 2018; Öztürk, 2011; Türk vd., 2020; Sünetci vd., 2016; Şenol ve Yıldız, 2013) gibi davranışları içermektedir. Dijital/sanal şiddet; teknolojik araçlar kullanarak (Fidan ve Yeşil, 2018: 19) partneri sık sık aramak, sosyal medya sayfasında kimlerle iletişim kurduğunu kontrol etmek, konum istemek, tehdit etmek, istenmeyen özel bilgi ve/veya fotoğraflarını yayınlamak, fotoğraflarının altına hakaret içeren yorumlar yazmak, sosyal medya hesaplarının şifrelerini istemek, cinsel içerikli fotoğraf paylaşmaya zorlamak şeklindeki tutum ve davranışları kapsamaktadır (Bakır ve Kalkan, 2019; Fidan ve Yeşil, 2018; Kaplan, 2020; Ocak, 2017). Israrlı takip (stalking/musallat olma) ise "ayrılmış olunan ya da halen birlikte olunan partnerin, diğerini sürekli izlemesi ve takip etmesidir" (Fidan ve Yeşil, 2018: 19). "Israrlı takipte kişi, bireyi iş yerine giderken evine giderken takip edebilir, evine, iş yerine, okuluna hediyeler yollayabilir, sosyal medya üzerinden iletişim kurmaya çalışabilir, aile ve arkadaş çevresiyle görüşüp birey hakkında bilgi alabilir" (Kaplan, 2020: 536).

Toplumsal cinsiyet rolleri, toplumdaki mevcut kültürel değerler, toplumda flört şiddetini besleyen kabul görmüş/benimsenmiş mitler, yaş farkı, partnerlerden birinin ya da her ikisinin alkol ve madde kullanması, ailenin eğitim seviyesi ve ekonomik durumu, sosyal destekten yoksun olmak, arkadaş etkisi, depresyon, anksiyete veya travma ile ilişkili hastalıklara sahip olmak flört şiddetini ortaya çıaran önemli risk faktörlerindendir (Akcan, 2020; Akın, 2015; Akış vd., 2019; Aslan vd., 2008; Aslan vd., 2020; Ayyıldız ve Taylan, 2018; Kızmaz, 2006; Mihçıokur ve Karatay vd., 2018; Öngün ve Ünsal, 2018). Küçükken ailede yaşanan şiddete tanıklık etmek veya şiddete bizzat maruz kalmak da flört ilişkisinde ya fail ya da mağdur olmayı belirleyen diğer faktörlerdir (Makepeace, 1981). Aile içi şiddete şahit olma ya da maruz kalma çocuklarda fiziksel ve psikolojik sorunlara neden olmakta, yetişkinlik döneminde tıbbi kökeni olmayan ağrılar, saldırganlık, yalnızlık, dikkat dağınıklığı gibi problemler ortaya çıkmaktadır (Solak, 2018).

Aile içi şiddet öyküsünün flört şiddetiyle ilişkisi Sosyal Öğrenme Kuramı çerçevesinde açıklanabilir. Sosyal Öğrenme Kuramı; şiddetin, öğrenilebilen bir davranış olduğunu öne sürmekte ve bu davranışın özellikle kişilerin erken çocukluk dönemlerinde şekillendiğini iddia etmektedir (Aslan vd., 2020: 368). Kurama göre şiddete uğrayan çocuklar ya şiddet davranışını dışsallaştırarak çevrelerini kontrol etmeyi ya da içselleştirerek yaşam boyunca şiddet içeren ilişkilere karşı savunmasız olmayı öğrenmektedirler. Şiddeti dışsallaştıran çocuklar, saldırgan davranışı daha sonraki romantik ilişkilerine yayarken; şiddeti içselleştirenler, başkaları tarafından uygulanan şiddetten geri çekilme veya bu şiddetten korunma yeteneklerini kaybettikleri bir "öğrenilmiş çaresizlik” içine girmektedir (Maas, Fleming, Herrenkohl ve Catalano, 2010). Kuram, çocukluktaki aile içi şiddet deneyiminin en sık erkeklerde şiddetin dişsallaştırılması yönünde bir etki oluşturduğunu ve bu nedenle erkeklerin ilişkilerinde daha sık saldırgan davranışlar gösterdiklerini, kızların ise şiddeti içselleştirmesi nedeniyle yakın ilişkilerinde daha çok mağdur olduklarını öne sürmektedir (McKee ve Payne, 2013). Dolayısıyla literatürde erkeklerde saldırganlık ve çocuk yaşta aile içi şiddet deneyimi arasında pozitif yönlü ilişkiyi ortaya koyan bulgulara sıklıkla rastlanmaktadır (Holtzworth-Munroe, Meehan, Herron, Rehman ve Stuart, 2000; Marshall ve Rose, 1987; O'Keefe, 1997; Ronfeldt, Kimerling ve Arias, 1998; Wolfe, Scott, Wekerle ve Pittman, 2001; Waltz, Babcock, Jacobson ve Gottman, 2000). Bununla beraber çocuk yaşta şiddete tanık olan veya şiddete maruz kalan kadınların, ilişkilerinde çoğunlukla mağduriyet yaşadıklarına yönelik bulgular da dikkat çekicidir (Sigelman vd., 1984; Wolfe vd., 2001). 
Yukarıdaki bilgiler 1şığında bu çalışma, gençlerde flört şiddetinin sıklığı, en sık uygulanan/maruz kalınan şiddet türleri ile cinsiyete göre flört şiddeti faili/mağduru durumunu üniversite örnekleminde ele almakta; erken dönem aile içi şiddet öyküsü (şiddete tanıklık etmek, şiddete bizzat maruz kalmak ve maruz kalınan şiddet türü) ile flört şiddeti faili/mağduru olma arasında ne düzeyde/yönde bir ilişki olduğunu analiz etmeyi amaçlamaktadır.

Batıda flört şiddetiyle ilişkili ilk çalışma, sosyolog Makepeace (1981) tarafından başlatılmıştır. Türkiye'de ise flört şiddetine yönelik çalışmalar; 2008 yılında Hacettepe Üniversitesi Kadın Sorunları Araştırma ve Uygulama Merkezi'nin gerçekleştirdiği çalışmayla başlamış olup (Flört Şiddeti: Akademide Ne Var Ne Yok?!., 2018); genellikle sağlık (psikiyatri, hemşirelik, ebelik, tıp) alanında (Demir ve Biçer, 2017; Karatay, Karatay, Baş ve Baş, 2018; Özan, Miman, Güvercin, Demiroğlu, Uyanıker, 2020; Özcebe vd., 2002; Yıldırım ve Terzioğlu, 2018) veya psikoloji/eğitim alanlarında (Akcan, 2020; Page ve İnci, 2008; Üstünel, 2020; Yolcu ve Akbay, 2020) yoğunlaşmıştır. Batıda sosyolojiyle başlayan araştırmalara karşın ülkemizde sosyolojik açıdan flört şiddetini inceleyen araştırmaların oldukça sınırlı olduğu dikkat çekmektedir (Kaplan, 2020; Sezer, Ertel ve Ertel, 2020). Bu durum, olgunun gerçek doğasını anlamayı da zorlaştırmaktadır. Zira bir olgunun ardındaki yapısal/kültürel faktörleri ortaya çıkaracak en önemli bilim dalının sosyoloji olduğu unutulmamalıdır (Giddens, 2008).

Bunun yanında hem batıda hem de Türkiye'deki çalışmalar çoğunlukla halihazırda flört şiddeti uygulama veya maruz kalma riskini artıran/azaltan faktörlere odaklanmıştır (Bergman, 1992; Molidor ve Tolman, 1998; O’keefe, 1997; Sharpe ve Taylor, 1999; Stets ve Pirog-Good, 1987). Her ne kadar flört şiddetini ortaya çıkaran risk faktörlerini incelemek önemli olsa da bir insanın şiddete başvurma ihtimalini yükselten faktörlerin neler olduğu üzerinde durmakta flört şiddetinin gerçek doğasını anlamak için gereklidir (Aberele ve Littlefield, 2001). Bu kapsamda çocukluk çağındaki şiddet deneyimi, şiddetin öğrenilmesindeki rolü nedeniyle incelenmesi gereken bir değişkendir. Nitekim literatürdeki pek çok çalışma, geçmişteki aile içi şiddet öyküsünün (çocukluk döneminde şiddete tanık olma ya da maruz kalma), flört şiddeti faili veya mağduru olma durumunu etkilediğini ortaya koymaktadır (Akcan, 2020; Akış vd., 2019; Makepeace, 1981, 1987; O'Keefe vd., 1986; O'Keefe, 1998; O'Keefe, 2005; Smith ve Williams, 1992; Temple vd., 2018; Yıldırım ve Terzioğlu, 2018). Stet ve Pirog-Good (1987), çocuklukta şiddete tanıklık etme ve maruz kalmanın bir arada olması durumunda, flört şiddeti üzerindeki bu etkinin daha güçlü olduğunu öne sürmektedir. Bu çalışma; iki değişken arasındaki ilişkiyi ayrıntılı analiz etmesi ve bu alandaki boşluğu doldurucu, sonraki çalışmalara da ilham verici olması açısından önemlidir. Bunlarla beraber bu çalışmanın bulgularının, şiddetle mücadele konusunda politika yapıcılara yol göstereceği/rehber olacağı düşünülmektedir.

\section{Yöntem}

\section{Araştırma Modeli}

Araştırma, nicel araştırma yöntemlerinden tarama modeline dayanmaktadır. Bu model, geçmişte veya şu anda var olan durumları betimlemek amacıyla kullanılmaktadır. Tarama modelleri; ilişkisel tarama ve nedensel karşılaştırmalı tarama olarak iki gruba ayrılmaktadır. İlişkisel tarama modeli; iki veya daha fazla değişken arasındaki ilişkileri saptamak için kullanılırken nedensel karşılaştırmalı model; var olan bir durumun nedenlerini, bu nedenleri 
etkileyen değişkenler ile bu etkinin sonuçlarını ortaya koymak amacıyla uygulanmaktadır (Karasar, 2012). Bu araştırmada çalışmanın amacına uygun olarak ilişkisel tarama modeli kullanılmıştır. Araştırmanın bağımlı değişkenleri flört şiddeti uygulama ve flört şiddetine maruz kalma durumudur. Bağımsız değişkenler ise çocukluk çağında aile içi şiddete tanıklık etmek, şiddete bizzat maruz kalmak ve maruz kalınan şiddet türüdür.

\section{Evren ve Örneklem / Çalışma Grubu / Katılımcılar}

Araştırma, üniversite öğrencilerinin uyguladığı ya da maruz kaldığı şiddetin, aile içi şiddetle ilişkisine odaklanmaktadır. Bu amaç doğrultusunda, Türkiye'nin farklı bölgelerindeki üniversitelerde araştırmanın yapılması böylece örneklemin çeşitliliğinin sağlanması ve elde edilen sonuçların genellenebilirliğinin yükseltilmesi hedeflenmiştir. Bu bağlamda Türkiye'nin batısını temsilen Çanakkale Onsekiz Mart Üniversitesi (ÇOMÜ), Orta Anadolu'yu temsilen Sivas Cumhuriyet Üniversitesi (SCÜ) ve Doğu-Güneydoğu bölgelerini temsilen Fırat Üniversitesi (FÜ), araştırmanın çalışma birimleri olarak seçilmiştir. Karadeniz ve Akdeniz bölgelerinde ise COVID-19 pandemisi nedeniyle üniversitelerin yüz yüze eğitime ara vermelerinden dolayı araştırma gerçekleştirilememiştir. Araştırmanın örneklemi, tesadüfi örnekleme tekniğiyle belirlenmiştir. Toplamda ulaşılan 813 öğrenciye anket uygulanmış, eksik dolduran 21 kişinin anket formunun çıkarılmasıyla geriye kalan 792 anket ile analizler yapılmıştır. Araştırmaya her üç üniversiteden de birbirine yakın bir katılım söz konusu olup (SCÜ=\%34,8, ÇOMÜ=\%33,1, FÜ=\%32,1); 523 (\%66)' ̈̈ lisans düzeyinde, 269 (\%34)'u önlisans düzeyinde öğrenim görmektedir. Katılımcıların 529'u kadın (\%66,8), 263'ü erkektir $(\% 33,2)$, yaş ortalamaları ise 20,50' dir (ss.. 1,39$)$.

\section{Veri Toplama Araçları}

Çalışmada kişisel bilgi formu ile çalışmanın amacına uygun olacak şekilde araştırmacılar tarafından hazırlanan flört şiddeti uygulama ve flört şiddetine maruz kalma durumunu ölçmeye dair soruların yer aldığı anket formu kullanılmıştır. Anket formu hazırlanırken literatür taramasında ulaşılan kuramlar ile çeşitli araştırmacılar tarafından yapılan alan araştırmalarında kullanılan anket sorularından yararlanılmıştır. Alanda yapılan çalışmalarda bu çalışmadakine benzer şekilde anket formu kullanıldığı görülmektedir. Bu nedenle çalışma kapsamında ölçme aracı olarak anket formu kullanılması uygun görülmüştür. Verilerin güvenilirliğini belirlemek için yapılan güvenilirlik testinde, Cronbach Alpha değeri 0,80 çıkmıştır. Bu değer, anketin güvenilir bir ölçme aracı olduğunu göstermektedir. Geçerlilik analizi ise güvenilirlik katsayısının karekökünün alınması ile hesaplanmıştır. Bu bağlamda geçerlilik için üst sınır 0,89 olarak hesaplanmıştır. Güvenilirlik, geçerlilik için üst sınır koyabilmekteyse de geçerliliği tam anlamıyla garantileyememektedir (Karagöz, 2008). Be sebeple oluşturulan anket formu, alanında uzman akademisyenlere inceletilmiş, verilen öneriler doğrultusunda düzenlemeler yapılmıştır. Düzenlenen yeni form, küçük bir gruba uygulanmış, anlaşılmayan veya yanlış anlaşılan sorular yeniden tasarlanarak, anketin içerik geçerliliği sağlanmaya çalışılmıştır. 


\section{Verilerin Toplanması ve Analizi}

Anketin uygulanması için Sivas Cumhuriyet Üniversitesi Sosyal Bilimler Etik Kurulu'ndan (15/1/2019 tarih ve 60263016-050.06.04-E.358652 sayıll) etik onay ile Rektörlüklerden araştırma izni alınmış, 2019 yılı Şubat ayı içerisinde araştırma yapılmıştır. Veriler, SPSS 23.0 paket programı kullanılarak analiz edilmiştir. Verilerin analizinde frekans ve yüzdelik dağılımları ile değişkenler arasındaki ilişkiyi ortaya koymak amacıyla Ki-Kare Bağımsızlık Testi kullanılmıştır.

Ki-Kare Bağımsızlık Testi, değişkenlerin her ikisinin nominal olması veya birisinin nominal diğerinin sıralı olması durumunda başvurulan bir analiz türü olup, iki değişkenin birbiriyle ilişkisini ortaya koymayı amaçlamaktadır. Analizde 2X2 tablolarda en küçük beklenen değerin 25'ten büyük olduğu durumlarda Pearson Ki-Kare sonucu, 5-25 arasında olduğu durumlarda Yates düzeltmeli Ki-Kare sonucu, 5'ten küçük olduğu durumlarda Fisher'in kesin olasılık testi sonucu yorumlanmıştır. NX2 veya MXN şeklinde olan tablolarda, $5^{\prime}$ ten küçük beklenen değer sayısının tablodaki hücrelerin \%20'sini geçmediği durumlarda Pearson Ki-Kare, diğer durumlarda ise Fisher'in kesin olasıllı testi sonucu değerlendirilmiştir (Güngör ve Bulut, 2008). Değişkenler arasında ilişkinin ortaya konduğu durumlarda ilişkinin gücünü test etmek amacıyla Phi değerine bakılmıştır. Phi katsayısı genellikle iki sonuçlu, iki değişken ( $2 \times 2$ boyutlu) arasındaki ilişkinin büyüklüğünü ölçmek amacıyla kullanılmaktadır. Katsayı değeri -1 ile +1 arasında değerler almaktadır (Karagöz, 2008).

\section{Bulgular}

Katılımcıların Flört İlişkili Durumları

Araştırmaya katılan öğrencilerin 603 (\%76,1)'ü daha önce en az bir flört ilişkisi yaşadıklarını söylemişlerdir. Şu an flört ilişkisi yaşadığını söyleyenlerin oranı ise yaklaşık \%39 (308)'dur. Buna göre toplamda 621 öğrenci $(\% 78,4)$ bugüne kadar en az bir flört ilişkisi yaşamıştır. Hâlihazırda flört ilişkisi olanların büyük bir kısmı $(\% 68,18)$, en çok 11 aydır ilişkilerinin devam ettiğini belirtmişlerdir (Bkz. Tablo 1).

Tablo 1. Flört İlişkisine Dair Betimsel İstatistikler

\begin{tabular}{lll|lll}
\hline Daha önceki flört ilişki & $\mathbf{n}$ & $\mathbf{\%}$ & Şu anki flört ilişki & $\mathbf{n}$ & $\%$ \\
\hline Evet & 603 & 76,1 & Evet & 308 & 38,9 \\
Hayır & 189 & 23,9 & Hayır & 484 & 61,1 \\
\hline Geçmiş ve şimdi flört edenler & & & Şu anki flört süresi & & \\
Var & 621 & 78,4 & En fazla 11 ay & 210 & 68,1 \\
Yok & 171 & 21,6 & $1-2$ yıl arası & 46 & 14,9 \\
Toplam & 792 & 100 & 3 ve üzeri & 52 & 16,8 \\
\hline
\end{tabular}




\section{Katılımcıların Flört Şiddeti ile İlişkili Durumları}

Geçmişte veya halihazırda flört ilişkisi yaşadığını söyleyen 621 katılımcının, \%72,1'i ilişkilerinde partnerine şiddet uyguladığını söylerken $\% 82,9^{\prime} u$, şiddet mağduru olduğunu ifade etmiştir. Tablo 2' de görüldüğü üzere katılımcıların hem şiddet faili hem de mağduru olma düzeyleri oldukça yüksektir. Cinsiyete göre şiddet faili ve mağduru olma durumları ayrı ayrı incelendiğinde erkeklerin $\% 74,9^{\prime} \mathrm{u}$, kadınların \%70,6'sı fail; erkeklerin \%83, $9^{\prime} \mathrm{u}$ kadınların \%82,4'ü mağdur olduğunu ifade etmiştir (Bkz. Tablo 2).

Tablo 2. Flört Şiddeti Uygulama/Flört Şiddetine Maruz Kalma

\begin{tabular}{lllll|lclc}
\hline & \multicolumn{2}{l}{ Şiddet uyguladım } & \multicolumn{2}{l|}{ Şiddet uygulamadım } & \multicolumn{2}{l}{ Şiddete uğradım } & \multicolumn{2}{c}{ Şiddete uğramadım } \\
\cline { 2 - 8 } & $\mathbf{n}$ & $\mathbf{\%}$ & $\mathbf{n}$ & $\mathbf{\%}$ & $\mathbf{n}$ & $\mathbf{\%}$ & $\mathbf{n}$ & $\mathbf{\%}$ \\
\hline Toplam & 448 & 72,1 & 173 & 27,9 & 515 & 82,9 & 106 & 17,1 \\
Erkek & 167 & 74,9 & 56 & 25,1 & 187 & 83,9 & 36 & 16,1 \\
Kadın & 281 & 70,6 & 117 & 29,4 & 328 & 82,4 & 70 & 17,6 \\
\hline
\end{tabular}

\section{Uygulanan/Maruz Kalınan Flört Şiddeti Türü}

Katılımcıların uyguladığı veya maruz kaldıkları şiddet türleri, araştırmacılar tarafından önceden belirlenmiş, bu bağlamda 30 cevap seçeneği hazırlanmıştır. Her bir katılımcının birden çok seçeneği işaretleyebilecekleri ifade edilmiştir. Frekans analizi sonuçlarına göre, katılımcılar genel olarak partnerlerine en çok azarlamak ve bağırmak şeklinde şiddet uygulamaktadırlar $(\% 59,15)$. Bunu sosyal medya hesaplarını kontrol etmek (şifrelerinin istenmesi, medya paylaşımlarına karışılması ve sosyal medyadaki arkadaşlarının takibi) $(\% 55,58)$ ve sürekli nerede olduğunu araştırmak/sormak $(\% 45,31)$ şeklinde uyguladıkları şiddet türü takip etmektedir. En çok maruz kalınan şiddet türleri ise sosyal medya hesaplarının kontrol edilmesi $(\% 79,01)$, sürekli nerede olduklarının sorulması $(\% 56,69)$ ve aşırı derecede kıskanılmaktır (\%53,57) (Bkz. Tablo 3).

Tablo 3. Uygulanan ve Maruz Kalınan Flört Şiddeti Türleri

\begin{tabular}{lcc|lcc}
\hline Uygulanan şiddet türü & $\mathbf{n}$ & $\mathbf{\%}$ & Maruz kalınan şiddet türü & $\mathbf{n}$ & $\%$ \\
\hline Azarlamak, bağırmak & 265 & 59,15 & Sosyal medya hesaplarının kontrolü & 354 & 79,01 \\
$\begin{array}{l}\text { Sosyal medya hesaplarını kontrol } \\
\text { etmek }\end{array}$ & 249 & 55,58 & Sürekli nerede olduğunun sorulması & 254 & 56,69 \\
Sürekli nerede olduğunu sormak & 203 & 45,31 & Aşırı derecede kıskanılmak & 240 & 53,57 \\
Aşırı derecede kıskanmak & 147 & 32,81 & Giyimine karışılması & 221 & 49,33 \\
Giyimine karışmak & 118 & 26,33 & $\begin{array}{l}\text { Arkadaş/aileyle } \\
\text { görüşmeninengellenmesi }\end{array}$ & 132 & 29,46 \\
İhmal etmek & 112 & 25 & Aşağllanmak, hakarete uğramak & 131 & 29,24 \\
İtmek, tartaklamak, 1sırmak & 100 & 22,32 & Çimdiklenmek & 130 & 29,1
\end{tabular}


Çimdiklemek

Arkadaş/aileyle görüşmeyi engellemek

Aşağılamak, hakaret etmek
89

19,86 İtilmek, tartaklanmak, 1sırılmak

$130 \quad 29,1$

$66 \quad 14,73$ Tekme- tokat yemek

\begin{tabular}{ll|l}
36 & 8,03 & Azarlanmak, bağırılmak
\end{tabular}
$75 \quad 16,74$

$72 \quad 16,07$

Geçmişte veya şu anda en az bir flörtü olup, flört şiddetine maruz kalan erkek sayısı 187, kadın sayısı ise $328^{\prime}$ dir. Kadınların en sık uyguladığı şiddet türleri; partnerlerinin sosyal medya hesapların kontrol etmek $(\% 51,8)$, partnerlerini azarlamak $(\% 49,3)$ ve onlara sürekli nerede olduklarını sormak $(\% 41,1)$ şeklindedir. Erkeklerde ise azarlamak ve bağırmak $(\% 55,0)$, sosyal medya hesaplarını kontrol etmek $(\% 42,2)$ ve kız arkadaşlarının giyimlerine karışmak $(\% 36,8)$ ilk üç sırada gösterdikleri şiddet türü olarak dikkat çekmektedir. Erkeklerin en sık maruz kaldığı şiddet türü, sosyal medya hesaplarının kontrol edilmesi $(\% 51,8)$, çimdiklenmek $(\% 49,1)$ ve sürekli nerede olduklarının sorulması $(\% 45,9)$ iken kadınlar sıklıkla sosyal medya hesaplarının kontrol edilmesi $(\% 66,1)$, giyimlerine karışılması $(\% 52,4)$ ve sürekli nerede olduklarının sorulması $(\% 51,2)$ şeklinde şiddet türlerine maruz kalmaktadır (Bkz. Tablo 4).

Tablo 4. Cinsiyet, Uygulanan Şiddet Türü, Maruz Kalınan Şiddet Türü

\begin{tabular}{|c|c|c|c|c|c|c|}
\hline & Uygulanan şiddet türü & $\mathbf{n}$ & $\%$ & Maruz kalınan şiddet türü & $\mathbf{n}$ & $\%$ \\
\hline \multirow{6}{*}{ 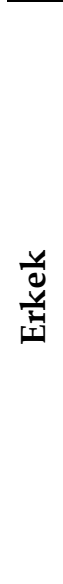 } & Azarlamak, bağırmak & 103 & 55,0 & $\begin{array}{l}\text { Sosyal medya hesaplarının } \\
\text { kontrol edilmesi }\end{array}$ & 97 & 51,8 \\
\hline & $\begin{array}{l}\text { Sosyal medya hesaplarını kontrol } \\
\text { etmek }\end{array}$ & 79 & 42,2 & Çimdiklenmek & 92 & 49,1 \\
\hline & Giyimine karışmak & 69 & 36,8 & $\begin{array}{l}\text { Sürekli nerede olduğunun } \\
\text { sorulması }\end{array}$ & 86 & 45,9 \\
\hline & Sürekli nerede olduğunu sormak & 68 & 36,3 & Aşırı derecede kıskanılmak & 79 & 42,2 \\
\hline & Aşırı derecede kıskanmak & 61 & 32,6 & İtilmek, tartaklanmak, ısırılmak & 75 & 40,1 \\
\hline & $\begin{array}{l}\text { İhmal edip kendi arkadaşlarıyla } \\
\text { görüşmek }\end{array}$ & 44 & 23,5 & Azarlanmak, bağırılmak & 58 & 17,6 \\
\hline \multirow{6}{*}{ 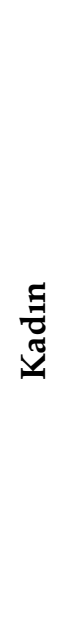 } & $\begin{array}{l}\text { Sosyal medya hesaplarının } \\
\text { kontrol edilmesi }\end{array}$ & 170 & 51,8 & $\begin{array}{l}\text { Sosyal medya hesaplarının } \\
\text { kontrol edilmesi }\end{array}$ & 217 & 66,1 \\
\hline & Azarlamak, bağırmak & 162 & 49,3 & Giyimine karışılması & 172 & 52,4 \\
\hline & Sürekli nerede olduğunu sormak & 135 & 41,1 & $\begin{array}{l}\text { Sürekli nerede olduğunun } \\
\text { sorulması }\end{array}$ & 168 & 51,2 \\
\hline & Aşırı derecede kıskanmak & 86 & 26,2 & Aşırı derecede kıskanılmak & 161 & 49,0 \\
\hline & $\begin{array}{l}\text { İhmal edip kendi arkadaşlarıyla } \\
\text { görüşmek }\end{array}$ & 68 & 20,7 & $\begin{array}{l}\text { Arkadaş/aileyle görüşmenin } \\
\text { engellenmesi }\end{array}$ & 91 & 27,7 \\
\hline & Aşağılamak, hakaret etmek & 46 & 14,0 & Aşağılanmak, hakarete uğramak & 81 & 24,6 \\
\hline
\end{tabular}




\section{KatılımolarınÇocuklukÇă̆ıŞiddetDeneyimleri}

Tablo 5'te görüleceği üzere katılımcıların \%32'si çocukluklarında aile içi şiddete tanıklık etmiştir. \%35,4'ü şiddete bizzat maruz kalmıştır. Ankette şiddete maruz kalanların hangi şiddet türüne uğradıkları da sorulmuş, katılımcıların birden fazla cevap seçeneğini işaretleyebilecekleri beyan edilmiştir. Bu nedenle maruz kalınan şiddet türüne verilen cevapların frekans ve yüzdelik dağılımlarının oranı yüzde yüzü geçmektedir. Cevaplar incelendiğinde şiddete maruz kaldıklarını söyleyenlerin en sık karşılaştığı şiddet türünün fiziksel şiddet $(\% 73,62)$ olduğu görülmektedir. Ardından duygusal şiddet gelmektedir (\%49,36). Cinsel şiddet, ihmal, ekonomik şiddet vb. Şiddet türleri çok az katılımcı tarafından işaretlendiği için diğer kategorisinde $(\% 9,36)$ birleştirilerek ifade edilmiştir. Cinsiyete göre çocukluk çağı şiddet deneyimleri ayrı ayrı analiz edildiğinde erkeklerin, kadınlara göre hem şiddete daha fazla tanıklık ettikleri $(\% 33,2)$ hem de daha fazla maruz kaldıkları dikkat çekmektedir $(\% 41,7)$. Yine erkekler fiziksel şiddet türüne $(\% 81,72)$ kadınlara kıyasla daha fazla maruz kalırken kadınların daha çok duygusal şiddetle $(\% 54,22)$ karşılaştığ görülmektedir (Bkz. Tablo 5).

Tablo 5. Çocukluk Çağ

\begin{tabular}{llllllllll}
\hline & Tanıklık & $\mathbf{n}$ & $\mathbf{\%}$ & Mağduriyet & $\mathbf{n}$ & $\mathbf{\%}$ & $\begin{array}{l}\text { Maruz kalınan } \\
\text { şiddet türü }\end{array}$ & $\mathbf{N}$ & $\%$ \\
\hline \multirow{2}{*}{ Toplam } & Evet & 199 & 32 & Evet & 235 & 37,8 & Fiziksel & 173 & 73,6 \\
& Hayır & 383 & 61,7 & Hayır & 351 & 56,5 & Duygusal & 116 & 49,3 \\
& Kayıp veri & 39 & 6,3 & Kayıp veri & 35 & 5,6 & Diğer & 22 & 9,3 \\
\hline \multirow{2}{*}{ Erkek } & Evet & 74 & 33,2 & Evet & 93 & 41,7 & Fiziksel & 76 & 81,7 \\
& Hayır & 126 & 56,5 & Hayır & 110 & 49,3 & Duygusal & 39 & 41,9 \\
& Kayıp veri & 23 & 10,3 & Kayıp veri & 20 & 9 & Diğer & 7 & 7,52 \\
\hline \multirow{3}{*}{ Kadın } & Evet & 125 & 31,4 & Evet & 142 & 35,7 & Fiziksel & 97 & 68,3 \\
& Hayır & 257 & 64,6 & Hayır & 241 & 60,6 & Duygusal & 77 & 54,2 \\
& Kayıp veri & 16 & 4 & Kayıp veri & 15 & 3,8 & Diğer & 15 & 10,5 \\
\hline
\end{tabular}

\section{Aile İçi Şiddete Tanıklık Etme ve Flört Şiddeti Iliş̧kisi}

Çocukken aile içi şiddete tanıklık etme ile flört şiddeti uygulama arasında bir ilişkinin (bağımlılığın) olup olmadığı, kikare bağımsızlık testi ile ortaya konulmuştur. Elde edilen bulgular, iki değişken arasında istatistiksel bakımdan anlamlı, pozitif yönde ancak zayıf bir bağlantı olduğunu göstermektedir $(\chi 2=6,792, \mathrm{sd}=1, \mathrm{p}<0.05$, Phi=0,11). İlişkinin pozitif yönde olması, şiddete tanıklık eden veya etmeyen grupların her ikisinin de şiddet uygulama eğiliminde olduklarını göstermektedir. Ancak şiddete tanıklık edenlerin \%84'ü şiddet uygularken şiddete tanıklık etmeyenlerin \%70'i şiddet uyguladığını söylemiştir. Buradan 
çocukluğunda şiddete tanıklık ettiğini söyleyenlerin, şiddete tanıklık etmeyenlere kıyasla partnerlerine yönelik daha çok flört şiddeti uyguladıkları söylenebilir.

Benzer şekilde çocukluğunda aile içi şiddete tanıklık etme ile flört şiddetine maruz kalma arasında da pozitif yönde zayıf bir ilişki bulunmuştur $(\chi 2=5,352, \mathrm{sd}=1, \mathrm{p}<0.05$, phi=0,10). Hem aile içi şiddete tanıklık edenler hem de etmeyenler, şiddete daha çok maruz kaldıklarını beyan etmişlerdir ancak oranlara bakıldığında şiddete tanıklık edenlerin, flört şiddeti mağduru olma oranlarının şiddete tanıklık etmeyip, flört şiddetine maruz kaldığını söyleyenlerden daha yüksek olduğu görülmektedir (Şiddete tanıklık edenlerin \%89,4'ü, şiddete tanıklık etmeyenlerin \%81,7'si şiddet mağduru olduklarını ifade etmişlerdir). Bu durumda, çocukluğunda aile içi şiddete tanıklık edenlerin daha çok flört şiddetine maruz kaldığı sonucu açıkça görülmektedir (Bkz.Tablo 6).

Tablo 6. Şiddete Tanıklık ile Flört Şiddeti Arasındaki İlişki

\begin{tabular}{|c|c|c|c|c|c|}
\hline \multirow{2}{*}{ Şiddete Tanıklık } & \multicolumn{5}{|c|}{ Flört şiddeti uygulama } \\
\hline & Uyguladım & Uygulamadım & $\chi^{2}$ & sd. & $\mathrm{p}$ \\
\hline \multirow{3}{*}{$\begin{array}{l}\text { Evet } \\
\text { Hayır }\end{array}$} & $\mathbf{N}$ & $\mathbf{N}$ & \multirow{4}{*}{6,792} & \multirow{4}{*}{1} & \multirow{4}{*}{0,00} \\
\hline & 160 & 39 & & & \\
\hline & 268 & 115 & & & \\
\hline Toplam & 428 & 154 & & & \\
\hline \multirow{3}{*}{ Şiddete Tanıklık } & \multicolumn{5}{|c|}{ Flört şiddetine maruz kalma } \\
\hline & Uğradım & Uğramadım & $\chi^{2}$ & sd. & $\mathrm{p}$ \\
\hline & $\mathbf{N}$ & $\mathbf{n}$ & \multirow{4}{*}{5,352} & \multirow{4}{*}{1} & \multirow{4}{*}{0,02} \\
\hline Evet & 178 & 21 & & & \\
\hline Hayır & 313 & 70 & & & \\
\hline Toplam & 491 & 91 & & & \\
\hline
\end{tabular}

Flört şiddeti uygulama için Pearson Ki- Kare testi $\mathrm{p}<0,05$; Maruz kalma için Yates düzeltmeli Ki- Kare testi $\mathrm{p}<0,05$

\section{Küçükken Aile İçi Şiddete Maruz Kalma ve Flört Şiddeti Arasındaki İlişki}

Çocukken aile içi şiddete maruz kalma ile flört şiddeti uygulama arasında bir ilişkinin olup olmadığını ortaya koymak amacıyla yapılan kikare analizi sonuçlarına göre, iki değişken arasında bir ilişki saptanmamıştır. Diğer bir deyişle bu iki değişken birbirine bağımlı değildir $(\chi 2=2,593, p>0.05)$. Ancak araştırmada çocukluğunda şiddete maruz kalma ile flört şiddetine maruz kalma arasında pozitif yönlü zayıf bir ilişki saptanmıştır $(\chi 2=4,116, s d=1, p<0.05$, phi=0,09). Hem çocukluğunda şiddete uğrayanların $(\% 88,1)$ hem de uğramayanların $(\% 81,5)$ büyük çoğunluğu, ilişkilerinde partnerlerinden şiddet gördüklerini söylemişlerdir. Bu, iki değişken arasındaki pozitif ilişkiyi ortaya koymaktadır. Ancak oranlara bakıldığında çocuk 
yaşta aile içi şiddete maruz kalanların $(\% 88,1)$, flört şiddetine uğrama oranlarının diğer gruba kıyasla (\%81,5) dahayüksek olduğunu göstermektedir (Bkz. Tablo 7).

Tablo 7. Çocukken Aile İçi Şiddete Maruz Kalma- Flört Şiddeti Arasındaki İlişki

\begin{tabular}{|c|c|c|c|c|c|}
\hline Şiddete & \multicolumn{5}{|c|}{ Flört şiddeti uygulama } \\
\hline \multirow[t]{2}{*}{ Maruz Kalma } & Uyguladım & Uygulamadım & $\chi^{2}$ & sd. & $\mathrm{p}$ \\
\hline & $\mathbf{N}$ & $\mathbf{n}$ & \multirow{4}{*}{2,593} & \multirow{4}{*}{1} & \multirow{4}{*}{0,10} \\
\hline Evet & 181 & 54 & & & \\
\hline Hayır & 248 & 103 & & & \\
\hline Toplam & 429 & 157 & & & \\
\hline Şiddete & \multicolumn{5}{|c|}{ Flört şiddetine maruz kalma } \\
\hline \multirow[t]{2}{*}{ Maruz Kalma } & Uğradım & Uğramadım & $\chi^{2}$ & sd. & $\mathrm{p}$ \\
\hline & $\mathbf{N}$ & $\mathbf{n}$ & \multirow{4}{*}{4,116} & \multirow{4}{*}{1} & \multirow{4}{*}{0,04} \\
\hline Evet & 207 & 28 & & & \\
\hline Hayır & 286 & 65 & & & \\
\hline Toplam & 493 & 93 & & & \\
\hline
\end{tabular}

Flört şiddeti uygulama için Pearson Ki- Kare testi $p>0,05$; Maruz kalma için Pearson Ki- Kare testi $\mathrm{p}<0,05$

\section{Çocukken Maruz Kalınan Şiddet Türü ve Flört Şiddeti Arasındaki İlişki}

Yukarıda da ifade edildiği üzere katılımcılar, maruz kaldıkları şiddet türü ile ilgili soruya birden fazla cevap seçeneğini işaretleyebilecekleri yönünde bilgilendirilmişlerdir. Analiz esnasında bu soruya verilen yanıtlar çerçevesinde katılımcıların çok büyük bir kısmının fiziksel ve psikolojik şiddeti işaretledikleri görülmüştür. Diğer kategorisi içerisinde değerlendirilen şiddet türlerini işaretleme oranı oldukça azdır. Bu nedenle şiddet türleri yeniden kategorize edilmiş; bu bağlamda yalnızca fiziksel şiddete maruz kalanlar, yalnızca psikolojik şiddete maruz kalanlar ve her iki şiddet türüne de maruz kalanlar olmak üzere üç kategori belirlenmiştir. Diğer seçeneği içindeki şiddet türlerine maruziyet oldukça az olduğundan bu kategori analizden çıarılmıştır.

Ki-kare analizi sonucunda her iki değişken ile maruz kalınan şiddet türü arasında bir ilişki olmadığ1 tespit edilmiştir (Flört şiddeti uygulama için $\chi 2=2,756$, sd=2, p>0,05; flört şiddetine maruz kalma için $\chi 2=3,400, \mathrm{sd}=2, \mathrm{p}>0,05)$. Esasen şiddet türlerinden birisi veya her ikisine maruz kaldığını söyleyenlerin flört şiddeti uygulama oranının; çocukken herhangi bir şiddet türüne veya türlerine uğrayıp, "partnerime şiddet uygulamadım" diyenlere kıyasla daha yüksek olduğu görülmektedir. Buna göre yalnızca fiziksel şiddete maruz kalıp, flört şiddeti uygulayanların oranı \%87,4; yalnızca duygusal şiddete uğrayıp, flört şiddeti uygulayanların oranı \%70,4; her ikisine birden maruz kalıp, flört şiddeti uygulayanların oranı \%83,6'dır. Buna karşın uğradıkları şiddet türüne göre partnerlerine şiddet uygulamadıklarını 
söyleyenlerin oranı sırasıyla \%21,4; \%29,1; \%16,4'tür. Buradan çocukken herhangi bir şiddet türüne uğramanın, flört şiddeti uygulama ihtimalini yükselttiği ancak bunun istatistiksel anlam düzeyinde olmadığı görülmektedir. Aynı durum, şiddet türü ve flört şiddetine maruz kalma arasında da geçerlidir. Oranlar dikkate alındığında, çocukluğunda herhangi bir şiddet türüne uğrayıp, ilerleyen dönemde partnerinden şiddet görenlerin oranının, görmeyenlerden daha yüksek olduğu görülmektedir. Buna göre yalnızca fiziksel şiddete uğrayıp, flört şiddetine uğrayanların oranı \%90,2; yalnızca duygusal şiddete uğrayıp, flört şiddeti uygulayanların oranı \%81,8; her ikisine uğrayıp, flört şiddeti uygulayanların oranı \%91,8'dir. Buna karşın uğradıkları şiddet türüne göre partnerlerinden şiddet görmediklerini söyleyenlerin oranı sırasıyla \%9,8; \%18,2; \%7'tür. Buradan çocukken herhangi bir şiddet türüne uğramanın, flört şiddetine uğrama ihtimalini yükselttiğini ancak yukarıda da ifade edildiği üzere bunun istatistiksel anlam düzeyinde olmadığı görülmektedir (Bkz. Tablo 8).

Tablo 8. Küçükken Maruz Kalınan Şiddet Türü- Flört Şiddeti Arasındaki İlişki

\begin{tabular}{|c|c|c|c|c|c|}
\hline \multirow{3}{*}{ Şiddet Türü } & \multicolumn{5}{|c|}{ Flört şiddeti uygulama } \\
\hline & Uyguladım & Uygulamadım & $\chi^{2}$ & sd. & $\mathbf{p}$ \\
\hline & $\mathbf{N}$ & $\mathbf{N}$ & & & \\
\hline Fiziksel & 88 & 24 & & & \\
\hline Psikolojik & 39 & 16 & 2,756 & 2 & 0,252 \\
\hline Her ikisi & 51 & 10 & & & \\
\hline Toplam & 178 & 50 & & & \\
\hline \multirow{3}{*}{ Şiddet Türü } & \multicolumn{5}{|c|}{ Flört şiddetine maruz kalma } \\
\hline & Uğradım & Uğramadım & $\chi^{2}$ & sd. & p \\
\hline & $\mathbf{N}$ & $\mathbf{N}$ & & & \\
\hline Fiziksel & 101 & 11 & & & \\
\hline Psikolojik & 45 & 10 & 3,400 & 2 & 0,183 \\
\hline Her ikisi & 56 & 5 & & & \\
\hline Toplam & 202 & 26 & & & \\
\hline
\end{tabular}

\section{Tartışma, Sonuç ve Öneriler}

$\mathrm{Bu}$ araştırma, çocukluktaki aile içi şiddet deneyimi ve flört şiddeti arasında bir ilişki olup olmadığını incelemekte; gençler arasındaki flört şiddetinin ne düzeyde ve sıklıkta olduğunu, gençlerin en sık uyguladıkları/maruz kaldıkları şiddet türlerini, flört şiddetinin cinsiyete göre dağılımını ortaya koymaktadır.

Araştırmada elde edilen bulgulardan ilki, gençler arasında flört şiddetinin yaygın olduğudur. Bulgu, literatürdeki benzer araştırma bulgularını desteklemektedir (Akış vd., 2019; Barter, 2009; Foshee vd., 2016; Harned, 2002; Tarı Selçuk vd., 2018; Shen, Chiu ve Gao, 2012). Gençler arasında flört şiddetinin yaygınlaşması, şiddetin gittikçe olağan bir durum 
olarak algılanması ile açıklanabilir çünkü flört şiddetinin sıklığı arttıkça normalleşmekte, bu da uygulama sıklığının artmasına neden olmaktadır (Ayyıldız ve Taylan, 2018). Bunun yanında gençlerin, şiddetle ilgili farkındalıklarının düşük olması, bu nedenle çoğu davranışı şiddet olarak algılamamaları da partnerler arasında şiddeti kaçınılmaz kılabilmektedir. Özellikle şiddetin görünürlüğünün düşük olduğu duygusal şiddet davranışları, flört ilişkisi içerisindeki taraflar arasında sıklıkla uygulanabilmektedir (Karatay, vd., 2018). Ek olarak ataerkil toplum yapısının getirdiği toplumsal cinsiyet rolleri nedeniyle günümüzde hala bazı şiddet davranışlarının (kıskançlık ve kısıtlamalar), sevgi göstergesi olarak kabul edilmesi de gençler arası şiddeti artırabilmektedir (Akcan, 2020; Sünetçi vd., 2016).

Araştırmada dikkat çeken ikinci bulgu hem erkeklerin hem de kadınların benzer düzeyde partnerlerine şiddet uyguladığıdır. Aynı şekilde iki grup birbirine yakın oranda flört şiddetine maruz kalmışlardır. Bulgu, şiddet içeren ilişkide her iki tarafın hem fail hem de mağdur olarak hareket edebileceğini göstermekte; literatürde flört şiddetinin karşılıklı olduğunu ortaya koyan araştırmaları desteklemektedir (Akış, vd., 2019; Burke, Stets ve Pirog-Good, 1989; Gray ve Foshee, 1997; Harned, 2001; Malik, Sorenson ve Aneshensel, 1997; Marshall ve Rose, 1988; Stets ve Straus, 1989; Straus, 2004, 2008, 2010; Straus ve Ramírez, 2007). Flört ilişkisinin çift yönlülüğü, mağdur tarafın saldırganın ulaştığı pozitif sonuçları görüp, şiddeti bir sorun çözme yöntemi olarak taklit edebilmesinden kaynaklanabilir. Bu da Sosyal Öğrenme Kuramının şiddetin öğrenilen bir davranış olduğu varsayımını doğrulamaktadır (Lewis ve Fremouw, 2001). Bununla birlikte taraflardan birisinin saldırgan davranışla karşı karşıya kaldığında aynı zamanda şiddet içeren bir savunma refleksi göstermesinin mümkün olduğu da gözden kaçırılmamalıdır. Nitekim yapılan bir çalışma, kadınların çoğunlukla kendilerini korumak amacıyla şiddete başvurduğunu ortaya koymuştur (Elmquist vd., 2016; Sezer vd., 2020). Her ne kadar söz konusu görüşler kadınların şiddet kullanma nedenlerini açıklayıp her iki grup için şiddetin karşılıklı olduğunu ortaya koysa da gözden kaçırılmaması gereken bir nokta vardır. O da erkeklerin oluşabilecek toplumsal baskı nedeniyle şiddet içeren davranışlarını saklama eğiliminde olabilmeleridir. Sosyal istenirlik kuralı gereği erkekler toplumun kendilerinden beklediği cevapları verme eğiliminde olabilir. Bu da onların flört şiddetine ilişkin soruları doğru cevaplama ihtimallerini düşürebilir. Buna karşın kadınların kendilerini daha rahat ifade edebilmeleri de uyguladıkları şiddeti açıkça söyleme cesareti verebilir. Bu da iki cinsiyet grubunun benzer düzeyde şiddet uyguladıkları gibi bir yanılgıya neden olabilir. Dolayısıla bu durumun var olup olmadığını ortaya koyacak çalışmalara ihtiyaç vardır (Lewis ve Fremouw, 2001).

Araştırmanın üçüncü bulgusu; gençler arasında en sık uygulanan ve maruz kalınan şiddet türünün, psikolojik şiddet olduğudur. Bu kapsamda sosyal medya hesaplarının kontrolü ile partnerin sürekli nerede olduğunun takibi, kıskançlık katılımcıların hem en sık uyguladığı hem de en çok maruz kaldığı eylemler olarak dikkat çekmektedir. Bu durum, her iki cinsiyet grubu için de benzerdir. Yapılan bazı araştırmalar, bu araştırma bulgusuna benzer şekilde kadın ve erkek için psikolojik yolla gerçekleştirilen şiddetin, diğer tüm şiddet türlerinden daha yaygın olduğunu (Murray ve Kardatzke, 2007; Akış vd., 2019; Açıkgöz vd., 2018) ve psikolojik saldırganlıklarda çift yönlülüğün daha sık görüldüğünü (Rubio-Garay vd., 2017) ortaya koymuştur. Psikolojik şiddet, flört ilişkisi içinde daha sık görülmekle birlikte daha az bilinmekte ve daha az tepki gösterilmektedir. Psikologlara göre bunun nedeni, psikolojik şiddetin fark edilmesinin zor olmasıdır. Psikolojik şiddete maruz kalmış kişilerin, bir başkasına psikolojik şiddet uygulamaya daha eğilimli oldukları da 
görülmektedir (Ocak, 2021). Bu çalışma kapsamında örneklemin yarısı (\%50) çocukluğunda psikolojik şiddet gördüğünü beyan etmiştir. Bunların ilişkilerinde psikolojik şiddet uygulama olasılıkları yüksektir.

Araştırmanın dördüncü ve en önemli bulgularından birisi, anne veya babası arasındaki şiddete tanık olan çocukların, flört ilişkilerinde daha saldırgan oldukları ya da şiddete daha fazla maruz kaldıklarıdır. Bulgu, literatürle uyumludur zira yapılan pek çok çalışma, flört şiddeti uygulama ile çocuklukta şiddete tanık olma (Akış vd., 2019; Bernard ve Bernard, 1983; O'Keefe vd., 1986; Renner ve Whitney 2012; Smith ve Williams, 1992) veya flört şiddetine maruz kalma arasında pozitif yönlü ilişkiyi (Coffey Leitenberg, Henning, Bennett, ve Jankowski, 1996; vd.,1996; O’Keefe, 1998) gözler önüne sermektedir. Bu çalışmada çocukluk çağında şiddete tanıklık etmek ve flört ilişkisinde saldırgan davranış göstermek arasındaki ilişkinin, erkeklerin verdiği cevaplardan kaynaklandığı düşünülmektedir. Zira bu araştırma kapsamında yapılan ki kare analizinde çocuklukta şiddete şahit olmanın, erkeklerde saldırganlığı artırırken, kadınlarda flört şiddeti uygulama anlamında herhangi bir etkisinin olmadığı saptanmıştır. Bu durum muhtemelen önceki araştırmaların ortaya koyduğu gibi erkeklerin, ebeveynlerinin istismar edici davranışlarını model almalarının kadınlardan daha olası olmasından kaynaklanmaktadır (Marshall ve Rose, 1988; Payne ve Gainey, 2009). Erkeklerin çocukluklarında en sık şahit olduğu şiddet türünün fiziksel şiddet olması da ilerleyen dönemlerde saldırgan davranış sergilemeleri üzerinde etkili olabilir. Yapılan bir araştırmada, babalarının annelerine uyguladığı fiziksel şiddete şahit olan çocukların, yetişkinlik dönemlerindeki romantik ilişkilerinde fiziksel şiddet uygulama olasılıklarının diğerlerine kıyasla \%43 daha yüksek olduğu tespit edilmiştir (Gover vd., 2008). Bu çalışma kapsamında çocukluğunda şiddete şahitlik ettiğini söyleyen erkeklerin (74 kişi) \%72'sinin, aile içinde fiziksel şiddete şahit oldukları tespit edilmiştir. Bunun aksine çocukluk çağ 1 şiddete tanıklık etme ile flört şiddetine maruz kalma arasındaki ilişkinin ise kadınlardan kaynaklandığı düşünülmektedir çünkü yapılan ki kare analizinde çocuklukta şiddete şahit olmanın kadınlarda şiddete maruz kalmayı artırdığı erkeklerde ise böyle bir durumun söz konusu olmadığı görülmüştür. Sigelman ve arkadaşları (1984) özellikle küçük yaşta şiddete tanık olan kadınların, şiddeti içselleştirdiği için flört ilişkilerinde daha çok şiddete maruz kaldıklarını ortaya koymuştur. Gover ve arkadaşları (2008) özellikle babanın işlediği tacize tanık olmanın, kadınlar için fiziksel flört şiddeti mağduriyeti ile önemli ölçüde ilişkili olduğunu saptamıştır.

Araştırmanın beşinci bulgusu, çocukluğunda şiddete maruz kaldığını söyleyenlerin daha çok flört şiddeti uyguladıkları (Literatürde benzer bulgular için bkz. Coffey vd., 1996; Fagan, 2005; Magdol, Moffitt, Caspi, ve Silva, 1998; Marshall ve Rose, 1988) veya daha sik flört şiddeti mağduru olduklarıdır (Literatürde benzer bulgular için bkz. Akış vd., 2009; Fagan, 2005; Foshee, Benefield, Ennett, Bauman ve Suchindran, 2004; Makepeace, 1987; Stets ve Pirog-Good, 1987). Bu durumun çocukluk çağında şiddete maruz kalmanın, ilerleyen dönemler cinsiyetler açısından romantik ilişkilerde şiddet uygulama veya şiddet mağduriyeti riskinde bir farklılık oluşturmamasından kaynaklandığı düşünülmektedir (O'Keefe, 1997). Nitekim bu araştırma kapsamında çocukluk çağ1 şiddeti mağduru olan erkeklerin \%81'i, kadınların \%73'ü partnerlerine şiddet uygularken; çocukluk çă̆ 1 şiddeti mağduru erkeklerin $\% 88^{\prime} i$, kadınların ise $\% 89^{\prime}$ u kendi ilişkilerinde de flört şiddeti mağduru olmuşlardır. Bununla birlikte şiddete yönelik partnerlerin eşik değerleri de (tahammül düzeyi) şiddet içeren ilişki içerisinde olabilmelerinde bir etken olabilir. Bazı bireyler, şiddetle ilişkili son derece düşük tahammül düzeyine sahiptir ve bu nedenle ilişkilerinde en ufak bir 
sorunda şiddet kullanmaya meyillidir. Ya da tam tersi şiddetin dozu, mağdur için failin kontrolüne meydan okuyacak kadar tehdit edici görülmüyorsa kurban, çatışmadan uzaklaşabilir ve böylece daha çok şiddete maruz kalabilir. Çocukluk çağında şiddet deneyimi olanların, şiddete yönelik eşik değerlerinin düşük olması beklenmektedir. Geçmişte yaşanmış bir aile içi şiddet öyküsü olan kişi ya kontrol amaçlı kolayca şiddet uygulamakta ya da failin kontrolüne boyun eğerek, şiddeti pekiştirip mağduriyet yaşayabilmektedir (Stet ve Pirog-Good, 1987).

Araştırmanın son bulgusu, maruz kalınan şiddet türü ile flört şiddeti uygulama ve flört şiddetine maruz kalma arasında istatistiksel anlamda bir ilişki saptanmamasıdır. Şiddet türü fark etmeksizin çocukluğunda şiddete maruz kalanlar hem flört şiddetini daha fazla uygulamış hem de daha sık flört şiddetine maruz kalmıştır. Bu araştırma kapsamında fiziksel şiddet mağduru olanların \%83'ü, psikolojik şiddete maruz kalanların \%81'i, diğer şiddet türlerine maruz kalanların $\% 79^{\prime} \mathrm{u}$, flört ilişkilerinde daha sık hem fail hem de mağdur durumundadır. Bu durum, şiddetin tüm türlerinin davranışlar üzerindeki olumsuz sonuçlarını göz önüne koymaktadır. Kişi ne tür şiddete maruz kalırsa kalsın, bundan olumsuz yönde etkilenebilmekte ve ilişkilerinde şiddeti kullanmakta ya da şiddete boyun eğmektedir.

Tüm bulgular birlikte değerlendirildiğinde çocukluk çağı şiddet deneyiminin flört ilişkisinin önemli belirleyicilerinden olduğunu söylemek mümkündür. Araştırmanın sonuçları dikkate alındığında aşağıdaki öneriler sunulabilir:

a. Flört ilişkisinin yaygınlığı, yalnızca evlilik birliği içerisindeki eşlere aile danışmanlığı verilmesinin yetersiz olduğunu göstermektedir. Şiddetin bir sarmal şeklinde geliştiği düşünüldüğünde, flört ilişkisi yaşayan gençlere de ilişki danışmanlığı verilmesi önem arz etmektedir. Yapılan pek çok çalışma flört şiddetinin, evlilikte aile içi şiddetin önemli belirleyicisi olduğunu ortaya koymuştur. Flört ilişkisinde partnerine şiddet uygulayan veya şiddete maruz kalanların, evliliklerinde de benzer bir durum yaşadıkları tespit edilmiştir (Meneghel ve Portella, 2017; Stets ve Pirog-Good, 1987).

b. Flört şiddeti ile ilgili çalışmalar son yıllarda artmasına karşın hala çalışılması gereken çok yönlü bir olgudur. Özellikle sosyoloji, psikoloji ve sosyal hizmet alanlarının bu konuya daha fazla ilgi göstermesi gerekmektedir. Söz konusu bilim dalları, olgunun bireysel ve yapısal unsurlarını ortaya çıkaracak hem faillere hem de mağdurlara yönelik psiko-sosyal müdahalelerin/desteklerin şekillenmesine katkı sunacaktır. Çocukluk çağında şiddet deneyimi, sonrasında şiddeti doğurduğundan sosyal hizmet uzmanlarına ve psikologlara hem şiddete yönelik motivasyonun azaltılmasında hem de uyguladığ 1 veya maruz kaldığ davranışın şiddet olduğunu bilmeyen/farkına olmayan partnerlerin şiddetle ilgili tutum ve davranışlarını değiştirme de (terapiler yoluyla) önemli sorumluluklar vermektedir (Stets ve Pirog-Good, 1987).

c. Şiddetin öğrenilen bir davranış olduğu gerçeği, ilköğretim düzeyinde şiddete ve toplumsal cinsiyet rollerine yönelik derslerin önemini ortaya koymaktadır. Şiddet ile mücadelede önleyici tedbirler önemlidir. Dolayısıyla bu bağlamda şiddet ve toplumsal cinsiyet ile ilgili derslerin, ilköğretim düzeyinde eğitim yapan kurumlarda (ailelerin de katılımıyla ya da bilgilendirilmesiyle) başlatılması daha mantıklı görülmektedir. 
d. Flört şiddeti ile mücadelede okul sosyal hizmetinin önemli katkı sunacağ1 açıktır. Bu nedenle okullarda bu alanın hızla yer bulması için gerekli adımların atılması önem arz etmektedir.

e. Toplumsal düzeyde, kitle iletişim araçları ve eğitim kursları aracılığıyla flört şiddetinin ve mağduriyetinin yaygınlık oranını azaltmak amacıyla halkın ve ergenlerin flört şiddetine ilişkin farkındalığını artırmak gereklidir. Ergenleri hedefleyen medya organlarında, geleneksel toplumsal cinsiyet kalıp yargılarının temsilini değiştirmek için de çaba gösterilmelidir (Stets ve Pirog-Good, 1987).

Her araştırmada olduğu gibi bu araştırmada da güçlü ve zayıf yönler mevcuttur. Bu araştırmanın güçlü yönü, diğer araştırmalara kıyasla nispeten daha geniş bir örneklemle gerçekleştirilmesidir. Örneklemin geniş tutulması, evreni temsil yeteneğini yükseltecektir.

Araştırmanın zayıf yönü ise yapılandırılmış anket formunun kullanılmasıdır. Anket soruları, katılımcılar tarafından doldurulmuştur. Bu tür araştırmalarda katılımcıların, toplumun kendilerinden beklenen cevapları verme eğiliminde oldukları görülmektedir. Bu da sonuçların, doğruluğunu tartışmaya açık hale getirmektedir (Gover vd., 2008). Bunun önüne geçebilmek için daha yenilikçi veri toplama tekniklerini uygulamak gereklidir. Bunun yanında kesitsel çalışmalar yerine uzunlamasına araştırmalar yapmak, flört şiddetinin gerçek doğasını ortaya koymaya katkı sunacaktır (Lewis ve Fremouw, 2001).

Araştırmanın bir diğer sınırlılı̆̆ı ise evren ve örneklemin sadece üniversite öğrencilerinden oluşmasıdır. Çalışmalarda diğer hedef kitlelerin (çalışan/işsiz gençlerin, evlenip boşanan ve sonrasında flört eden bireylerin/yetişkin bireylerin vb.) dahil edilmesi elde edilen bulguların genellenebilirliğini yükseltecektir.

\section{Kaynakça}

Aberle, C. C. ve Littlefield, R. P. (2001). Family functioning and sexual aggression in a sample of college men. Journal of Interpersonal Violence, 16(6), 565-579.

Açıkgöz, B., Açıkgöz, B., Karakoyun, A.R., Aslan-Yüksel, N., Akca, F., Demir-Akca, A.S. ve Ayoğlu, F.N. (2018). Tıp fakültesi 5. ve 6. sinıf öğrencilerinde flört şiddetinin değerlendirilmesi. Konuralp Tıp Dergisi, 10(2):168-174.

Akcan, G. (2020). Flört şiddeti: Psikopatolojik bir değerlendirme. Bartın Üniversitesi Edebiyat Fakültesi Dergisi, 5(2), 72-87.

Akış, N., Korkmaz, N.H., Taneri, P.E., Özkaya, G. ve Güney, E. (2019). Üniversite öğrencilerinde flört şiddeti sıklığı ve etkileyen etmenler. ESTÜDAM Halk Sağlı̆̆ı Dergisi,4(3),294-300.

Aslan, D., Vefikuluçay, D., Zeyneloğlu, S., Erdost, T. ve Temel, F. (2008). Ankara'da iki hemşirelik yüksekokulunun birinci ve dördüncü sinfflarından okuyan öğrencilerinin flört şiddetine maruz kalma, flört ilişkilerinde şiddet uygulama durumlarının ve bu konudaki görüşlerinin saptanması araştırması. Hacettepe Üniversitesi Kadın Sorunları Araştırma Merkezi.

Aslan, R., Bulut, M. ve Arslantaş, H. (2020). Flört şiddeti. Akademik Sosyal Araştırmalar Dergisi, 7(45), 365-384. 
Avşar-Baldan, G. ve Akış, N. (2017). Flört Şiddeti. Uludă̆ Üniversitesi Tıp Fakültesi Dergisi, $43(1), 41-44$.

Ayyıldız, A.B. ve Taylan, H.H. (2018). Üniversite öğrencilerinde flört şiddeti tutumları: Sakarya üniversitesi örneği. Akademik Sosyal Araştırmalar Dergisi, 6(86), 413-427.

Bakır, A. ve Kalkan, M. (2019). Siber flört istismarı, beden imgesi ve benlik saygısı arasındaki ilişki. Aile Psikolojik Danışmanlı̆̆ı Dergisi, 2(2), 21-51.

Barter, C. (2009). Inthe name of love: Partner abuse and violence in teenage relationships. British Journal of Social Work, 39(2), 211-233.

Bergman, L. (1992). Dating violence among highschool students. Social Work, 37(1), 21-27.

Bernard, M. L. ve Bernard, J. L. (1983). Violent intimacy: the family as a model for love relationships. Family Relations: An Interdisciplinary Journal of Applied FamilyStudies, 32(2), 283-286. doi: doi.org/10.2307/584688

Bilican-Gökkaya, V. (2018). Kadına Yönelik Şiddetin Diğer Bir Boyutu: Flört Şiddeti (Toplumsal Cinsiyet Bağlamında) A. Solak (Ed.), Şiddet ve Sosyal Travmalar,içinde (ss.. 400416). Ankara: Hegem Yayınları.

Burke, P., Stets, J. ve Pirog-Good, M. (1989). Gender identity, self-esteem, and physical and sexual abuse in dating relationships. M. Pirog-Good ve J. Stets (Eds.), Violence and dating relationships, içinde (ss. 72-93). NewYork: Praeger.

Coffey, P., Leitenberg, H., Henning, K., Bennett, R.T. ve Jankowski, M.K. (1996). Dating violence: the association between methods of coping and women's psychological adjustment. Violence and Victims. 11(3),227-38.

Demir, G. ve Biçer, S. (2017). Üniversite öğrencilerinin flört şiddetine maruz kalma durumları ve etkileyen faktörler. Turkish Studies Social Sciences, 12(13),171-188.

Elmquist, J., Wolford-Clevenger, C., Zapor, H., Febres, J., Shorey, R.C., Hamel, J. ve Stuart, G.L. (2016). A gender comparison of motivations for physical dating violence among college students. Journal of Interpersonal Violence. 31(1),186-203. doi: $10.1177 / 0886260514555130$

Fagan, A. A. (2005). The relationship between adolescent physical abuse and criminal offending: support for an enduring and generalized cycle of violence. Journal of Family Violence, 20(5), 279-290. doi:10.1007/s10896-005-6604-7

Fidan, F. ve Yeşil, Y. (2018). Flört şiddeti. Balkan ve Yakın Doğu Sosyal Bilimler Dergisi, 4(1),1624.

Flört Şiddeti: Akademide Ne Var Ne Yok?!. (2018). Milliyet Gazetesi (8 Mart 2018).Erişim tarihi: 3 Mart 2021. Erişim adresi: https://oyledegilboyle.org/2018/03/08/flort-siddetiakademide-ne-var-ne-yok/

Follette, V. M. ve Alexander, P. C. (1992). Datingviolence: Current and historical correlates. Behavioral Assessment, 14(1), 39-52.

Foshee, V. A., Bauman, K. E., Linder, F., Rice, J. ve Wilcher, R. (2007). Typologies of adolescent dating violence. Journal of Interpersonal Violence, 22(5),498-519. doi:10.1177/0886260506298829 
Foshee, V.A., Benefield, T.S., Ennett, S.T., Bauman, K.E. ve Suchindran, C. (2004). Longitudinal predictors of serious physical and sexual dating violence victimization during adolescence. Preventive Medicine, 39(5), 1007-1016. doi:10.1016/j.ypmed.2004.04.014

Foshee, V.A., McNaughton R.H.L., Chen, M.S., Ennett, S.T., Basile, K.C., DeGue, S. ve diğ. (2016). Shared risk factors for the perpetration of physical dating violence, bullying, and sexual harassment among adolescents exposed to domestic violence. Journal of Youth Adolescence, 45(4),672-686.

Giddens, A. (2008). Sosyoloji (5. Basım) (Cemal Güzel, Çev.) İstanbul: Kırmızı.

Gover, A.R., Kaukinen, C. ve Fox, K.A. (2008). The relationship between violence in the family of origin and dating violence among college students. Journal of Interpersonal Violence, 23(12),1667-1693. doi:10.1177/0886260508314330.

Gray, H. ve Foshee, V. (1997). Adolescent dating violence: Differences between one-sided versus mutually violent profiles. Journal of Interpersonal Violence, 12, 126-141.

Güngör, M. ve Bulut, Y. (2008). Ki-Kare testi üzerine. Doğu Anadolu Bölgesi Araştırmaları,7 (1), 84-89.

Harned, M. S. (2001). Abused women or abused men? An examination of the context and outcomes of dating violence. Violence and Victims, 16, 269-285.

Harned, M. S. (2002). A multivariate analysis of risk markers for dating violence victimization. Journal of Interpersonal Violence, 17, 1179-1197.

Hatipoğlu, Ü. S. (2010). Başkent Üniversitesi Öğrencilerinde Flört Şiddeti Prevalansı Anketi (Yayımlanmamış uzmanlık tezi). Başkent Üniversitesi Tıp Fakültesi Adli Tıp Anabilim Dalı.

Holtzworth-Munroe, A., Meehan, J. C., Herron, K., Rehman, U. ve Stuart, G. L. (2000). Testing the Holtzworth-Munroe and Stuart (1994) batterer typology. Journal of Consulting and Clinical Psychology, 68, 1000-1019.

Kaplan, B. (2020). Şiddetin toplumsal taşıyıcısı olarak flört şiddeti: Ankara örneği kent akademisi. Kent Kültürü ve Yönetimi Hakemli Elektronik Dergi, 13(3), 526-538.

Karagöz, Y. (2010). İlişki katsayıları ile öğrenci başarısını etkileyen faktörlerin belirlenmesi. Elektronik Sosyal Bilimler Dergisi, 9(32), 425-446.

Karasar, N. (2012). Bilimsel Araştırma Yöntemi. Ankara: Bilim Kitap Kırtasiye Yayınevi.

Karatay, M., Karatay, G., Gürarslan-Baş, N. ve Baş, K. (2018). Üniversite öğrencilerinin flört şiddetine ilişkin tutum ve davranışları. Sted, 27(1), 62-71.

Kızmaz, Z. (2006). Okullardaki şiddet davranışının kaynakları üzerine kuramsal bir yaklaşım. Cumhuriyet Üniversitesi Sosyal Bilimler Dergisi, 30(1),47-70.

Lewis, S.F. ve Fremouw, W. (2001). Dating violence: A critical review of the literatüre. Clinical Psychology Review, 21(1),105-127.

Maas, C. D., Fleming, C. B., Herrenkohl, T. I., ve Catalano, R. F. (2010). Childhood predictors of teen dating violence victimization. Violence and Victims, 25(2),131-149. https://doi.org/10.1891/0886-6708.25.2.131 
Magdol, L., Moffitt, T. E., Caspi, A. ve Silva, P. A. (1998). Developmental antecedents of partner abuse: A prospective-longitudinal study. Journal of Abnormal Psychology, 107(3), 375-389. doi:10.1037/0021-843x.107.3.375

Maharaj, N. (2019). Dating violence among college students: considerations for promoting ethical practice. Ethics and Social Welfare, 1-20. doi:10.1080/17496535.2018.1563202

Makepeace, J. (1981). Courtship violence among college students. Family Relations, 30,97-102.

Makepeace, J. (1987). Social factors and victim offender differences in courtship violence. Family Relations, 36, 87-91.

Malik, S., Sorenson, S. B. ve Aneshensel, C. S. (1997). Community and dating violence among adolescents: Perpetration and victimization. Journal of Adolescent Health, 21, 291-302.

Marshall, L. ve Rose, P. (1987). Gender, stress, and violence in adult relationships of a sample of college students. Journal of Social and Personal Relationships, 4, 299-316.

Marshall, L. ve Rose, P. (1988). Family of origin and courtship violence. Journal of Counseling and Development, 55, 414-418.

McKee, J. ve Payne, B. (2013). Witnessing domestic violence as a child and adulthood emotionality: do adults "feel" the consequences of exposure to partner abuse later in the life course. Journal of Aggression, MaltreatmentETrauma, 23: 318-331. Doi: 10.1080/10926771.2014.881947.

Meneghel S.H. ve Portella, A.O. (2017). Femicides: concepts, types and scenarios. CienSaúdeColet, 22(9), 3077-86.

Mıhçıokur, S. ve Akın, A. (2015). Flört şiddeti: Şiddetli sevgi. Sağlık ve Toplum, 2, 9-15.

Molidor, C. ve Tolman, R.M. (1998). Gender and contextual factors in adolescent dating violence. Violence Against Women, 4(2),180-194. doi:10.1177/1077801298004002004.

Murray, C. E. ve Kardatzke, K. N. (2007). Dating violence among college students: key issues for college counselors. Journal of College Counseling, 10(1), 79-89. doi:10.1002/j.21611882.2007.tb00008.x

O'Keefe, M. (1997). Predictors of dating violence among high school students. Journal of Interpersonal Violence, 12(4),546-568. doi:10.1177/088626097012004005.

O'Keefe, M. (1998). Factors mediating the link between witnessing interparental violence and dating violence. Journal of Family Violence, 13(1), 39-57.

O'Keefe, M. (2005) Teendating violence: A review of risk factors and prevention efforts. National Electronic Network on Violence Against Women, 1-13.

O'Keefe, M., Brockopp, K. ve Chew, E. (1986). Teendating violence. Social Work, 31, 465-468.

Offenhauer, P. ve Buchalter, A. (2011). Teendating violence: A literature review and annotated bibliography. Washington, DC: National Institute of Justice. Erişim Tarihi: 18.03.2021. Erişim Adresi: https://www.ojp.gov/pdffiles1/nij/grants/235368.pdf

Öngün, E. ve Ünsal, G. (2018). Üniversite yaşamında yakın ilişkiler ve istismar. Journal of Academic Research in Nursing (JAREN) Dergisi, (4) 1, 52-58. 
Özan, S., Miman, Ö., Güvercin, C.H. ve Demiroğlu-Uyanıker, Z. (2020). Yapılandırılmış bir eğitim modülünün, tıp fakültesï öğrencilerinin toplumsal cinsiyet ve flört şiddetine yönelik alg1 ve tutumlarına etkisi. Tıp Ĕ̆itimi Dünyası, 19(58),24-41.

Özcebe, H., Aslan, D., Karabiber, A.H., Küçüköztaş, M.F., Oransay, K. ve Ölmez, İ. (2002). Bir grup üniversite öğrencisinin "Flört Şiddeti” konusundaki görüşleri. Toplum ve Sosyal Hizmet, 13(1), 20-28.

Özdere, M. (2019). Üniversite öğrencilerinin flört şiddetine ilişkin tutumları. Akademik Sosyal Araştırmalar Dergisi, (95),314-331.

Özdere, M. ve Kürtül, N. (2018). Flört şiddeti eğitiminin, üniversite öğrencilerinin flört şiddetine ilişkin tutumlarına etkisi. Social Science Development Journal, 3(9),123-136.

Ocak, G. T. (2021). Psikolojik şiddet nasıl fark edilir? Erişim tarihi: 12 Mart 2021. Erişim Adresi: https://www.milliyet.com.tr/pembenar/psikolojik-siddet-nasil-fark-edilir-6449936

Öztürk, Ö. (2011). Türkiye'de kadına yönelik şiddet (Yayımlanmamış yüksek lisans tezi), Marmara Üniversitesi Sosyal Bilimler Enstitüsü.

Page, A.Z. ve İnce, M. (2008). Aile içi şiddet konusunda bir derleme. Türk Psikoloji Yazıları, 11(22),81-94.

Renner, L.M. ve Whitney, S.D. (2012). Risk factors for unidirectional and bidirectional intimate partner violence among young adults. Child Abuse Neglect, 36(1),40-52.

Ronfeldt, H. M., Kimerling, R. ve Arias, I. (1998). Satisfaction with relationship power and the perpetration of dating violence. Journal of Marriage and theFamily, 70-78.

Rubio-Garay, F., López-González, M. A., Carrasco, M. Á. ve Amor, P. J. (2017). The prevalence of dating violence: A systematic review. Papeles del Psicólogo, 38(2), 135-147.

Sezer, S., Ertel, R. ve Ertel, İ. (2020). Bir iktidar ve meşrulaştırma aracı olarak flört şiddeti: Muğla Kötekli Mahallesi örneği. Marmara Üniversitesi Kadın ve Toplumsal Cinsiyet Araştırmaları Dergisi, 4(2), 85-115.

Sharpe, D. ve Taylor, J. K. (1999). An examination of variables from a social-developmental model to explain physical and psychological dating violence. Canadian Journal of Behavioural Science, 31(3), 165.

Shen, A.C-T., Chiu, M.Y-L. ve Gao, J. (2012). Predictors of dating violence among chinese adolescents: the role of gender-role beliefs and justification of violence. Journal of Interpersonal Violence, 27(6),1066-1089. doi:10.1177/0886260511424497

Sigelman, C.K., Berry, C.J. ve Wiles, K.A. (1984). Violence in college students' dating relationships. Journal of Applied Social Psychology, 6,530-548.

Smith, J. P. ve Williams, J. G. (1992). From abusive house hold to dating violence. Journal of Family Violence, 7(2), 153-165.

Solak, A. (Ed.). (2018). Aile eksenli şiddetten sosyal travmalara. Ankara: HEGEM.

Stets, J.E. ve Pirog-Good, M.A. (1987). Violence in dating relationships. Social Psychology Quarterly, 50(3), 237-246.

Stets, J. E. ve Straus, M. A. (1989). The marriage license as a hitting license: A comparison of assaults in dating, cohabitating, and married couples. M.A. Straus ve R. J. Gelles (Eds.), 
Physicalviolence in American families: Risk factors and adaptations to violence in 8145 families içinde (ss. 33-52). New Jersey, Transaction Books.

Straus, M. (2004). Prevalence of violence against dating partners by male and female university students worldwide. Violence Against Women, 10, 790-811.

Straus, M. A. (2008). Prevalence and effects of mutuality in physical and psychological aggression against dating partners by university students in 32 Nations.Paper presented at the International Family Aggression Society Conference, Preston, UK.

Straus, M. A. ve Ramirez, I. L. (2007). Gendersymmetry in prevalence, severity, and chronicity of physical aggression against dating partners by university students in Mexico and USA. Aggressive Behavior, 33(4), 281-290. doi:10.1002/ab.20199

Sugarman, D. B. ve Hotaling, G. T. (1998). Dating violence: A review of contextual and risk factors. B. Levy (Ed.), Dating violence: Young women in danger içinde (ss. 100-118). Seattle, WA: SealPress.

Sünetci, B., Say, A., Gümüştepe, B., Enginkaya, B., Yıldızdoğan, Ç. ve Yalçın, M. (2016). Üniversite öğrencilerinin flört şiddeti algıları üzerine bir araştırma. Ufkun Ötesi Bilim Dergisi, 16(1), 56-83.

Şenol, D. ve Yıldız, S. (2013). Kadına yönelik şiddet algısı: Kadın ve erkek bakış açılarıyla. Ankara:Mutlu Çocuklar Derneği Yayınları.

Tarı-Selçuk, K., Avcı, D. ve Mercan, Y. (2018). Üniversite öğrencilerinde flört şiddetine maruziyet: Flört şiddetine yönelik tutumların ve toplumsal cinsiyet algısının şiddete maruziyet ile ilişkisi. Acıbadem Üniversitesi Sağlık Bilimleri Dergisi, 9(3),302-308.

Temple, J.R., Choi, H.J., Reuter, T., Wolfe, D., Taylor, C.A., Madigan, S. ve diğ. (2018) Childhood corporal punishment and future perpetration of physical dating violence. Journal of Pediatrix, 194,233-237.

Tuz, C., Öksüz, M.E. ve Tekiner, A.S. (2015). Kadına yönelik şiddet derecelendirme ölçeği ve mağdurların cinsel deneyimleri ölçeği Türkçe versiyonunun geçerlilik ve güvenilirliği. Eurasian Journal of FamilyMedicine, 4(2),83-89.

Türk, B. ve Tekin, A. (2018). Üniversite öğrencilerinde çocukluk çağı travmaları ile flört şiddeti arasındaki ilişkinin incelenmesi. Turaz Akademi, 84-91.

Türk, B., Hamzaoğlu, N. ve Yayak, A. (2020). Flört Şiddeti Üzerine Bir İnceleme. Türkiye Klinikleri Adli Tip ve Adli Bilimler Dergisi, 17(1), 73-81.

Üstünel, A.Ö. (2020). Eşit, güvenli, özgür ilişki: Üniversite öğrencilerine yönelik bir flört şiddeti önleme programının etki değerlendirmesi. Türk Psikoloji Yazıları, 23(45), 19-38.

Wolfe, D. A., Scott, K., Wekerle, C., ve Pittman, A. L. (2001). Child Maltreatment: Risk of Adjustment Problems and Dating Violence in Adolescence. Journal of the American Academy of Child EAdolescent Psychiatry, 40(3), 282-289. doi:10.1097/00004583-20010300000007

Waltz, J., Babcock, J. C., Jacobson, N. S., ve Gottman, J. M. (2000). Testing a typology of batterers. Journal of Consulting and Clinical Psychology, 68, 658-669. 
Yıldırım, S. ve Terzioğlu, F. (2018). Şiddetin farklı bir yüzü: Flört şiddeti, etkileri ve etkileyen faktörler. Anadolu Hemşirelik ve Sağlık Bilimleri Dergisi, 21(4),285-292.

Yolcu, D. ve Akbay, S.E. (2020). Datıng violence among unıversity students: The role of selfesteem, perceive drelationship self-efficacy and attachment styles. European Journal of Education Studies, 7(10),241-257.

Yumuşak, A. ve Şahin, R. (2014). Flörtte şiddete yönelik tutum ölçeklerinin güvenirlik ve geçerlik çalışması. Elektronik Sosyal Bilimler Dergisi, 13(49),233-252. 